\title{
Clinicopathological Role of Serum-Derived Hyaluronan-Associated Protein (SHAP)-Hyaluronan Complex in Endometrial Cancer
}

\author{
Hiromitsu Yabushita, ${ }^{1}$ Keita Iwasaki, ${ }^{1}$ Kouhei Kanyama, ${ }^{2}$ Yukihiko Obayashi, ${ }^{1}$ \\ Lisheng Zhuo, ${ }^{3}$ Naoki Itano, ${ }^{4}$ Koji Kimata, ${ }^{3}$ and Akihiko Wakatsuki ${ }^{1}$ \\ ${ }^{1}$ Department of Obstetrics and Gynecology, School of Medicine, Aichi Medical University, Nagakute-cho, Aichi 480-1195, Japan \\ ${ }^{2}$ Department of Obstetrics and Gynecology, Toyokawa City Hospital, Toyakawa, Aichi 422-8561, Japan \\ ${ }^{3}$ Research Complex for the Medicine Frontiers, School of Medicine, Aichi Medical University, Nagakute-cho, \\ Aichi 480-1195, Japan \\ ${ }^{4}$ Department of Molecular Biosciences, Faculty of Life Sciences, Kyoto Sangyo University, Motoyama, Kamigamo, Kita-ku, \\ Kyoto 603-8555, Japan
}

Correspondence should be addressed to Hiromitsu Yabushita, yab@aichi-med-u.ac.jp

Received 4 April 2011; Revised 4 July 2011; Accepted 4 July 2011

Academic Editor: Enrique Hernandez

Copyright (C) 2011 Hiromitsu Yabushita et al. This is an open access article distributed under the Creative Commons Attribution License, which permits unrestricted use, distribution, and reproduction in any medium, provided the original work is properly cited.

\begin{abstract}
The role of hyaluronan (HA), serum-derived HA-associated protein (SHAP)-HA complex and hyaluronan synthase (HAS) in endometrial carcinomas was investigated. The relationship of metalloproteinase (MMP) and its inhibitor (TIMP) with HA and the SHAP-HA complex was also examined. The expression of HAS1 was related to the depth of myometrial invasion and lymph-vascular space involvement. The serum levels of HA, SHAP-HA complex, MMP-9, and TIMP-1 were increased in related with the depth of myometrial invasion, histological grade and lymph-vascular space involvement. They were also higher in the HAS1-positive group compared to -negative group. The serum concentrations of HA and SHAP-HA complex had a significant correlation with the MMP-9 and TIMP-1. The patients with elevated SHAP-HA complex had the shorter disease-free survival. The multivariate analysis revealed that the SHAP-HA complex was the independent variable for disease-free survival of endometrial cancer patients. In conclusion, the elevation of serum SHAP-HA complex depended on the HAS1 expression and the SHAP-HA complex is a useful marker to predict disease recurrence in endometrial cancer patients. The SHAP-HA complex may promote the lymph-vascular space involvement and the synthesis and activation of MMP- 9 and TIMP-1 in the progression of endometrial cancer.
\end{abstract}

\section{Introduction}

The incidence rate for endometrial cancer has been increasing in Japan [1]. Clinicopathological studies show that poor prognosis is related to cervical invasion of malignant cells, deep myometrial invasion of malignant cells, lymph node metastasis, and lymph-vascular space involvement of malignant cells $[2,3]$. The multistage process of tumor invasion and metastasis depends on several mechanisms, including the stimulation of cell growth by growth factors, destruction of the extracellular matrix by proteolytic enzymes, neovascularization due to the presence of angiogenic factors, and cell to cell or stroma adhesion regulated by cell adhesion molecules.

Hyaluronan (HA) is an extracellular polysaccharide typically present in the extracellular matrix of some epithelial and neural tissues. HA is particularly abundant in connective tissues. HA controls cell migration, differentiation, and proliferation, thereby influencing tissue morphogenesis, wound healing, and tumor growth $[4,5]$. HA levels correlate with the invasiveness and metastatic capacity of tumor cells [6]. Increased HA concentrations may help invasion by providing 
a less dense matrix for cancer cells [7], stimulating cancer cell motility, and forming an immunoprotective coat for cancer cells [8].

Three mammalian hyaluronan synthase (HAS) genes, HAS1, HAS2, and HAS3, are involved in hyaluronan biosynthesis [9], and their expressions vary depending upon tissue-, age- and pathophysiological differences and are important to investigate the biological function of hyaluronan, especially in tumor cell malignancy, because the overexpression of HAS makes tumor cells more aggressive with significant differences in the malignant activity among the three HAS genes [10]. The three isoforms of HAS have been shown to synthesize distinct types of hyaluronans with different structural characteristics and functions [9].

Associations with various HA-binding proteins, including proteoglycans, result in tremendously diverse physiological functions for HA. Extracellular matrix containing HA as a major component, called HA-rich matrix, plays important roles in regulating cellular behavior in a variety of physiological and pathological processes via cell-surface HA receptors, such as CD44 and receptor for hyaluronan-mediated motility [11].

SHAP was originally discovered as the complex with HA in HA-rich matrix from cultured mouse dermal fibroblasts and was found to be derived from serum supplemented to culture media, and thereby named as serum-derived HAassociated proteins (SHAPs) [12, 13]. Then, SHAP was found to correspond to the heavy chains of plasma inter- $\alpha$-trypsin inhibitor (ITI) family molecules and be covalently bound to HA via a unique ester bond [12-14]. ITI family molecules are synthesized by hepatocytes and secreted into the blood at high concentrations [15]. The heavy chains of these molecules are derived from 3 different genes, and either 1 or 2 of the chains are covalently bound to the light chain, bikunin, to form ITI family members such as ITI, pre- $\alpha$-trypsin inhibitor, and inter- $\alpha$-trypsin-like inhibitor [16]. During the formation of SHAP-HA complexes, HA is substituted for the chondroitin sulfate chain of bikunin, accompanied by the release of bikunin $[12,17]$. Released bikunin is excreted in urine as urinary trypsin inhibitor (UTI).

Matrix metalloproteases (MMPs) play a crucial role in tissue remodeling in a variety of physiological and pathological processes, similar to the roles of HA. In malignant tumor, HA may possibly influence the expression of MMP-9 as well as the conversion of the inactive pro-forms to active forms $[18,19]$.

We previously reported the role of HA and HAS1 in endometrial cancer [20]. The expression of HAS1 and serum HA level were related to the depth of myometrial invasion, histological grade, and lymph-vascular space involvement. Serum HA level was higher in the HAS1-positive group than in the HAS1-negative group. The goal of the present study was to determine if the levels of HA, the SHAP-HA complex, UTI, and the immunohistochemical expression of HAS correlate with the clinicopathological manifestations and clinical outcome of endometrial carcinoma. The causal relationships of the serum levels of HA and the SHAP-HA complex with those of metalloproteinase and its inhibitor in serum were also examined and discussed.

\section{Materials and Methods}

2.1. Clinical Samples. Formalin-fixed, paraffin-embedded tissue, serum, and urine were obtained from 50 patients with endometrioid adenocarcinoma of the endometrium. All patients attended the gynecology clinic at Aichi Medical University Hospital and were diagnosed as stage I. Of them, nine cases who did not undergo lymphadenectomy had no finding suggesting the lymph node metastasis in a presurgical CT scan examination. The surgical specimens were evaluated by more than one gynecologic pathologists, and they also evaluated the immunohistochemical examination. Serum and urine were also obtained from 50 postmenopausal donors with the negative endometrial cytology. The mean age of endometrial cancer patients was $57.24 \pm 9.28$ years, and that of healthy women was $54.52 \pm 6.34$ years observed in healthy women, which was almost the same as that of the patients $(P=0.09)$. This study was approved by the regional ethics committee of Aichi Medical University, School of Medicine. Written informed consent was obtained from all participants prior to study enrollment.

2.2. Immunohistochemistry. The polyclonal antibodies against HAS1, HAS2, and HAS3 were raised in rabbits by subcutaneous injection of the following synthetic peptides; VRRLCRRRSGGTRVGV, corresponding to amino acids 568-582 of HAS1; CGRRKKGQQYDMVLDV, corresponding to the amino acids 537-552 of HAS2; CGKKPEQYSLAFAEV, corresponding to amino acids 541-555 of HAS3, which had been coupled to keyhole limpet hemocyanin. The specificity of the purified antibodies has been confirmed [10, 21]. Immunostaining was performed by the avidin-biotinperoxidase complex method using a VECTASTAIN ABC kit Elite (Vector Laboratories Inc., Burlingame, Calif, USA). The prepared $3 \mu \mathrm{m}$ sections were deparaffinized and rehydrated. After treatment with $0.25 \%$ trypsin solution at $37^{\circ} \mathrm{C}$ for 10 minutes, the sections were incubated at $4^{\circ} \mathrm{C}$ overnight with the antibodies against HAS1, HAS2 and HAS3. The chemogen used was 3,3' -diaminobenzidine tetrahydrochloride (Dojindo, Kumamoto, Japan). Sections were counterstained with hematoxylin for microscopic examination. Sections were defined as having positive expression when $>90 \%$ of tumor cells were intensely stained.

2.3. Measurement of Serum Concentrations for HA, SHAPHA Complex, MMP-2, MMP-9 and TIMP-1, and Urine Concentration of UTI. Concentrations of HA in serum were measured using an inhibitory enzyme-linked immunosorbent assay (ELISA) (Seikagaku Corp., Tokyo, Japan) [22]. Briefly, HA-conjugated bovine serum albumin (BSA) plates were washed 3 times with phosphate-buffered saline (PBS) containing $0.1 \%$ Tween 20 (PBS-T). Then, $50 \mu \mathrm{L}$ sample (diluted 1:5 10 with PBS-T) and $50 \mu$ L biotinylated HABP $(0.5 \mu \mathrm{g} / \mathrm{mL}$ in $1 \% \mathrm{BSA} / \mathrm{PBS}-\mathrm{T})$ were applied to each well, and plates were incubated at $37^{\circ} \mathrm{C}$ for $1 \mathrm{~h}$. After washing with PBS-T, $50 \mu \mathrm{L}$ horseradish peroxidase-streptavidin (1:500) was added to each well, and plates were further incubated at $37^{\circ} \mathrm{C}$ for $1 \mathrm{~h}$. Color development was achieved by incubating with $50 \mu \mathrm{L}$ of tetramethylbenzidine (TMB) solution at $37^{\circ} \mathrm{C}$ 
for $10 \mathrm{~min}$; then, the reaction was stopped by adding $50 \mu \mathrm{L}$ $1 \mathrm{M} \mathrm{HCl}$. Absorbance at $450 / 630 \mathrm{~nm}$ (absorbance at $450 \mathrm{~nm}$ absorbance at $630 \mathrm{~nm}$ ) was measured with an immuno Mini NI-2300 spectrophotometer. Assays were performed in triplicate.

The levels of the SHAP-HA complex in sera were determined by measuring the amount of SHAPs bound to HA using a sandwich ELISA [22]. Microtiter plates were coated with HABP $(4 \mu \mathrm{g} / \mathrm{mL}$ in $0.1 \mathrm{M}$ sodium carbonate buffer; $\mathrm{pH} 9.5$ ) at $4^{\circ} \mathrm{C}$ for $15 \mathrm{~h}$. Wells were washed twice with $200 \mu \mathrm{L}$ PBS, followed by blocking with $200 \mu \mathrm{L}$ of $3 \%$ BSA in PBS-T at room temperature for $1 \mathrm{~h}$. After washing the wells 3 times with $200 \mu \mathrm{L}$ PBS-T, $50 \mu \mathrm{L}$ sample (serum diluted 1:5 10 with 1\% BSA/PBS-T) was added to each well. Then, plates were incubated at $37^{\circ} \mathrm{C}$ for $1 \mathrm{~h}$. After washing, $25 \mu \mathrm{L}$ of rabbit antihuman ITI antibody (diluted $1: 3000$ with $1 \% \mathrm{BSA} / \mathrm{PBS}-\mathrm{T}$ ) and $25 \mu \mathrm{L}$ of HRP-conjugated goat antirabbit immunoglobulins antibody (diluted 1:3000 with $1 \%$ BSA/PBS-T) were added to each well and incubated at $37^{\circ} \mathrm{C}$ for $1 \mathrm{~h}$. Wells were washed 3 times then were incubated with $50 \mu \mathrm{L}$ of $\mathrm{TMB}$ solution at $37^{\circ} \mathrm{C}$ for $10 \mathrm{~min}$. The reaction was stopped by the addition of $50 \mu \mathrm{L} 1 \mathrm{M} \mathrm{HCl}$, and absorbance at $450 / 650 \mathrm{~nm}$ was measured. Assays were performed in triplicate.

The urine levels of UTI were measured using an inhibitory ELISA [22]. Microtiter plates were coated with UTI $(2 \mu \mathrm{g} / \mathrm{mL}$ in $0.1 \mathrm{M}$ sodium carbonate buffer; $\mathrm{pH} 9.5)$ at $4^{\circ} \mathrm{C}$ overnight and then blocked with 3\% BSA as above. The plates were washed 3 times with PBS-T, then $50 \mu \mathrm{L}$ sample (urine diluted $1: 5 \sim 10$ with PBS) and $50 \mu \mathrm{L}$ anti-UTI antibodies were applied to each well and incubated at $37^{\circ} \mathrm{C}$ for $1 \mathrm{~h}$. Wells were washed, and $100 \mu \mathrm{L}$ HRP-conjugated goat antirabbit antibody was added to each well. Plates were then further incubated at $37^{\circ} \mathrm{C}$ for $1 \mathrm{~h}$. After washing with PBS$\mathrm{T}$, color development was achieved by incubation with $50 \mu \mathrm{L}$ $\mathrm{TMB}$ solution at $37^{\circ} \mathrm{C}$ for $10 \mathrm{~min}$, then the reaction was stopped using $50 \mu \mathrm{L} 1 \mathrm{M} \mathrm{HCl}$. Absorbance at $450 / 650 \mathrm{~nm}$ was measured. Assays were performed in triplicate.

Concentrations of MMP-2, MMP-9, and TIPM-1 in sera were measured with a one-step sandwich ELISA kit for each (Fuji Chemical Co., Toyama, Japan) as reported previously [23-25]. A serum $(10 \mu \mathrm{L})$ was mixed with $100 \mu \mathrm{L}$ of $50 \mu \mathrm{g} / \mathrm{L}$ each antibody conjugated with HRP in $10 \mathrm{mM}$ sodium phosphate buffer ( $\mathrm{pH} 7.0$ ) containing $10 \mathrm{~g} / \mathrm{L}$ BSA, $10 \mathrm{nM}$ EDTA, and $0.1 \mathrm{M} \mathrm{NaCl}$. A $100 \mu \mathrm{L}$ aliquot of the mixture was transferred to microplate well previously coated with each antibody. The plate was incubated for $60 \mathrm{~min}$ at room temperature and then washed 3 times with PBS. Color development was achieved by incubation with $100 \mu \mathrm{L}$ of citric acidsodium phosphate buffer containing $o$-phenylenediamine and hydrogen peroxide at room temperature for $20 \mathrm{~min}$. The reaction was stopped with $100 \mu \mathrm{L} 1 \mathrm{M} \mathrm{HCl}$, and the absorbance at $492 \mathrm{~nm}$ was measured. Assays were performed in triplicate.

2.4. Statistical Analysis. The statistical significance of differences among different categories of expression was analyzed using the unpaired $t$-test, the chi-square test, and two-way
ANOVA. Pearson correlation coefficient was used to test for significant relationships. Disease-free survival was analyzed by the Kaplan-Meier method and log-rank test, and the potential significance of plural prognostic factors for diseasefree survival was analyzed by Cox proportional hazard model. $P$ values less than 0.05 were considered statistically significant.

\section{Results}

3.1. HAS, HA, SHAP-HA Complex, UTI, MMP-2, MMP9, and TIMP-1 in Relation to the Clinicopathological Manifestations. In endometrioid adenocarcinoma of uterine corpus, the HAS1, HAS2, and HAS3 were expressed in tumor cells as our previous report (Figure 1) [20]. Of the 50 endometrial cancer cases, the positive immunohistochemical expression was found in 29 cases for HAS1, 33 cases for HAS2, and 29 cases for HAS3. The expression of HAS1 was related to the depth of myometrial invasion and lymphvascular space involvement although it had no relationship with the histological grade. On the other hand, the expression of HAS2 and HAS3 had no relationship with the depth of myometrial invasion, histological grade, and lymphvascular space involvement (Table 1). The serum levels of HA, the SHAP-HA complex, MMP-9, TIMP-1, and UTI were higher in the endometrial cancer group than in the control group, while the serum MMP-2 levels had no difference between both groups (Table 2). The serum levels of HA, the SHAP-HA complex, MMP-9, and TIMP-1 were significantly increased in the patients with the deeper myometrial invasion (Table 3). The urine levels of UTI and serum levels of HA, the SHAP-HA, complex and TIMP-1 were higher in the patients with the poorly differentiated (G3) tumor, compared with the moderately differentiated (G2) tumor and well-differentiated (G1) tumor. The serum levels of HA, the SHAP-HA complex, MMP-9, TIMP-1, and the urine level of UTI were significantly increased in the patients with the lymph-vascular space involvement (Table 3).

3.2. Relationship of Immunohistochemical Expressions of HAS Isoforms with Serum Levels of HA, the SHAP-HA Complex, MMP-2, MMP-9 and TIMP-1, and Urine Level of UTI. The serum levels of the SHAP-HA complex, MMP-9, and TIMP1 were higher in the HAS1-positive group than in the HAS1negative group. However, the expression of HAS2 and HAS3 was unrelated to them (Table 4). The serum levels of HA and the SHAP-HA complex had a significant correlation with the MMP-9, and TIMP-1 in endometrial cancer patients (Table 5).

3.3. HAS, HA, SHAP-HA Complex, UTI, MMP-2, MMP-9, and TIMP-1 Levels in Relation to the Disease-Free Survival and Overall Survival. The Kaplan-Meier analysis revealed that the patients with elevated serum levels of the SHAPHA complex and TIMP-1 had a shorter disease-free survival compared with those with normal levels of them. Also, the Kaplan-Maier analysis revealed that patients with the deeper myometrial invasion and poorly differentiated tumor 


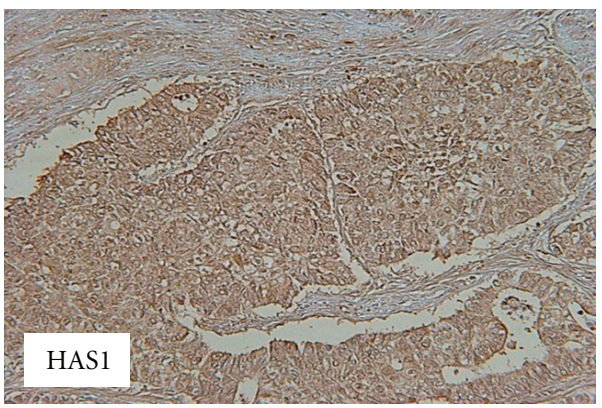

(a)

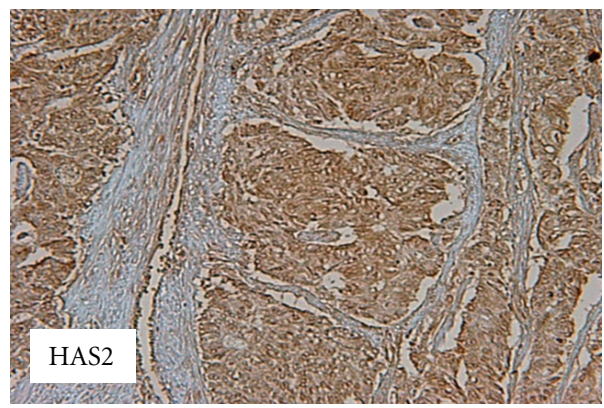

(b)

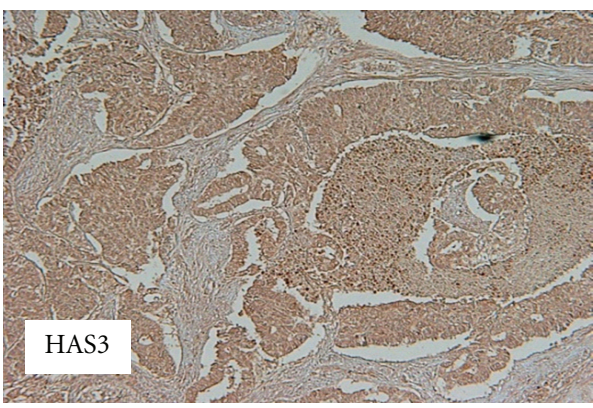

(c)

FIGURE 1: Immunohistochemical visualization of HAS1, HAS2, and HAS3 in endometrioid adenocarcinoma of the uterine corpus $(\times 400)$.

TABLE 1: Expression of HAS1, HAS2, and HAS3 in relation to the depth of myometrial invasion, histological grade, and lymph-vascular space involvement in patients with endometrial cancer.

\begin{tabular}{|c|c|c|c|c|c|c|c|}
\hline & \multirow[b]{2}{*}{$n$} & \multicolumn{2}{|c|}{ HAS1 expression } & \multicolumn{2}{|c|}{ HAS2 expression } & \multicolumn{2}{|c|}{ HAS3 expression } \\
\hline & & $\begin{array}{l}\text { Negative } \\
(N=21)\end{array}$ & $\begin{array}{l}\text { Positive } \\
(N=29)\end{array}$ & $\begin{array}{l}\text { Negative } \\
(N=18)\end{array}$ & $\begin{array}{l}\text { Positive } \\
(N=32)\end{array}$ & $\begin{array}{l}\text { Negative } \\
(N=21)\end{array}$ & $\begin{array}{l}\text { Positive } \\
(N=29)\end{array}$ \\
\hline \multicolumn{8}{|c|}{ Myometrial invasion } \\
\hline Less than half & 30 & 16 & 14 & 11 & 19 & 14 & 16 \\
\hline \multirow[t]{2}{*}{ More than half } & 20 & 5 & 15 & 7 & 13 & 7 & 13 \\
\hline & & \multicolumn{2}{|c|}{$\chi^{2}=3.96, P=0.0467$} & \multicolumn{2}{|c|}{$P>0.9999$} & \multicolumn{2}{|c|}{$P=0.5602$} \\
\hline \multicolumn{8}{|l|}{ Histological grade } \\
\hline G1/G2 & 40 & 19 & 21 & 16 & 24 & 15 & 25 \\
\hline \multirow[t]{2}{*}{ G3 } & 10 & 2 & 8 & 2 & 8 & 6 & 4 \\
\hline & & \multicolumn{2}{|c|}{$P=0.1604$} & \multicolumn{2}{|c|}{$P=0.2947$} & \multicolumn{2}{|c|}{$P=0.2859$} \\
\hline \multicolumn{8}{|c|}{ Lymph-vascular space involvement } \\
\hline Absent & 28 & 16 & 12 & 10 & 18 & 12 & 16 \\
\hline \multirow[t]{2}{*}{ Present } & 22 & 5 & 17 & 8 & 14 & 9 & 13 \\
\hline & & \multicolumn{2}{|c|}{$\chi^{2}=5.99, P=0.0213$} & \multicolumn{2}{|c|}{$P>0.9999$} & \multicolumn{2}{|c|}{$P=0.8898$} \\
\hline
\end{tabular}

TABLE 2: Serum HA, SHAP-HA complex, MMP-2, MMP-9, TIMP-1, and UTI in 50 endometrial cancer patients and 50 healthy women.

\begin{tabular}{lccccccc}
\hline & $n$ & $\begin{array}{c}\mathrm{HA} \\
(\mathrm{ng} / \mathrm{mL})\end{array}$ & $\begin{array}{c}\text { SHAP-HA } \\
\text { complex } \\
(\mathrm{U} / \mathrm{mL})\end{array}$ & $\begin{array}{c}\mathrm{UTI} \\
(\mu \mathrm{g} / \mathrm{mL})\end{array}$ & $\begin{array}{c}\text { MMP-2 } \\
(\mathrm{ng} / \mathrm{mL})\end{array}$ & $\begin{array}{c}\text { MMP-9 } \\
(\mathrm{ng} / \mathrm{mL})\end{array}$ & $\begin{array}{c}\text { TIMP-1 } \\
(\mathrm{ng} / \mathrm{mL})\end{array}$ \\
\hline Healthy control & 50 & $52.74 \pm 23.87$ & $1.884 \pm 1.418$ & $1.930 \pm 1.47$ & $707.84 \pm 124.20$ & $277.76 \pm 117.68$ & $154.16 \pm 29.37$ \\
Endometrial cancer & 50 & $368.23 \pm 233.28$ & $3.294 \pm 2.209$ & $7.004 \pm 15.044$ & $703.94 \pm 182.54$ & $736.40 \pm 524.24$ & $223.80 \pm 100.79$ \\
& & $P<0.0001$ & $P=0.0002$ & $P=0.0197$ & $P=0.9009$ & $P<0.0001$ & $P<0.0001$ \\
\hline
\end{tabular}

Values are shown as mean \pm SD. 
TABle 3: Serum HA, SHAP-HA complex, MMP-2, MMP-9, TIMP-1, and UTI in relation to the depth of myometrial invasion, histological grade, and lymph-vascular space involvement in patients with endometrial cancer.

\begin{tabular}{|c|c|c|c|c|c|c|c|}
\hline & $n$ & $\begin{array}{c}\mathrm{HA} \\
(\mathrm{ng} / \mathrm{mL})\end{array}$ & $\begin{array}{l}\text { SHAP-HA } \\
\text { complex } \\
(\mathrm{U} / \mathrm{mL})\end{array}$ & $\begin{array}{c}\text { UTI } \\
(\mu \mathrm{g} / \mathrm{mL})\end{array}$ & $\begin{array}{l}\text { MMP-2 } \\
(\mathrm{ng} / \mathrm{mL})\end{array}$ & $\begin{array}{l}\text { MMP-9 } \\
(\mathrm{ng} / \mathrm{mL})\end{array}$ & $\begin{array}{l}\text { TIMP-1 } \\
(\mathrm{ng} / \mathrm{mL})\end{array}$ \\
\hline \multicolumn{8}{|c|}{ Myometrial invasion } \\
\hline Less than half & 30 & $236.94 \pm 145.14$ & $2.151 \pm 2.030$ & $5.737 \pm 13.679$ & $720.03 \pm 197.67$ & $598.90 \pm 439.17$ & $199.27 \pm 81.09$ \\
\hline \multirow[t]{2}{*}{ More than half } & 20 & $565.18 \pm 200.37$ & $5.009 \pm 3.888$ & $8.905 \pm 17.080$ & $679.80 \pm 158.96$ & $942.65 \pm 582.89$ & $260.60 \pm 117.41$ \\
\hline & & $P<0.0001$ & $P=0.0014$ & $P=0.4713$ & $P=0.4508$ & $P=0.0215$ & $P=0.0336$ \\
\hline \multicolumn{8}{|l|}{ Histological grade } \\
\hline G1/G2 & 40 & $295.39 \pm 180.95$ & $2.443 \pm 2.397$ & $4.422 \pm 11.565$ & $699.50 \pm 186.84$ & $694.58 \pm 504.76$ & $209.40 \pm 92.94$ \\
\hline \multirow[t]{2}{*}{ G3 } & 10 & $659.63 \pm 191.00$ & $6.698 \pm 3.883$ & $17.330 \pm 22.462$ & $721.70 \pm 172.34$ & $903.70 \pm 594.45$ & $281.40 \pm 115.21$ \\
\hline & & $P<0.0001$ & $P<0.0001$ & $P=0.0136$ & $P=0.7347$ & $P=0.2635$ & $P=0.0421$ \\
\hline \multicolumn{8}{|c|}{$\begin{array}{l}\text { Lymph-vascular space } \\
\text { involvement }\end{array}$} \\
\hline Absent & 28 & $247.75 \pm 147.98$ & $2.340 \pm 2.838$ & $2.107 \pm 1.767$ & $682.32 \pm 185.10$ & $575.71 \pm 328.58$ & $179.75 \pm 36.44$ \\
\hline \multirow[t]{2}{*}{ Present } & 22 & $521.57 \pm 234.18$ & $4.508 \pm 3.304$ & $13.236 \pm 21.246$ & $731.46 \pm 179.66$ & $940.91 \pm 651.32$ & $279.86 \pm 126.95$ \\
\hline & & $P<0.0001$ & $P=0.0161$ & $P=0.0080$ & $P=0.3500$ & $P=0.0129$ & $P=0.0002$ \\
\hline
\end{tabular}

Values are shown as mean \pm SD.

TABle 4: Serum HA, SHAP-HA complex, MMP-2, MMP-9, TIMP-1, and UTI in relation to the expression of HAS1, HAS2, and HAS3 in patients with endometrial cancer.

\begin{tabular}{lccccccc}
\hline & $n$ & $\begin{array}{c}\text { Hyaluronan } \\
(\mathrm{ng} / \mathrm{mL})\end{array}$ & $\begin{array}{c}\text { SHAP-HA } \\
\text { complex } \\
(\mathrm{U} / \mathrm{mL})\end{array}$ & $\begin{array}{c}\text { UTI } \\
(\mu \mathrm{g} / \mathrm{mL})\end{array}$ & $\begin{array}{c}\text { MMP-2 } \\
(\mathrm{ng} / \mathrm{mL})\end{array}$ & $\begin{array}{c}\text { MMP-9 } \\
(\mathrm{ng} / \mathrm{mL})\end{array}$ & $\begin{array}{c}\text { TIMP-1 } \\
(\mathrm{ng} / \mathrm{mL})\end{array}$ \\
\hline $\begin{array}{l}\text { HAS1 expression } \\
\text { Negative }\end{array}$ & 21 & $298.22 \pm 154.04$ & $1.168 \pm 0.917$ & $2.390 \pm 2.047$ & $719.10 \pm 207.79$ & $504.76 \pm 205.00$ & $183.38 \pm 67.60$ \\
Positive & 29 & $418.93 \pm 268.23$ & $4.833 \pm 3.403$ & $10.345 \pm 19.119$ & $692.97 \pm 164.84$ & $904.14 \pm 617.70$ & $253.07 \pm 111.36$ \\
& & $P=0.0705$ & $P<0.0001$ & $P=0.0643$ & $P=0.6223$ & $P=0.0065$ & $P=0.0142$ \\
\hline HAS2 expression & & & & & & & \\
Negative & 18 & $349.8 \pm 216.78$ & $2.851 \pm 2.624$ & $3.756 \pm 5.973$ & $734.22 \pm 212.04$ & $787.28 \pm 525.09$ & $244.44 \pm 120.89$ \\
Positive & 32 & $378.6 \pm 244.82$ & $3.543 \pm 3.511$ & $8.831 \pm 18.127$ & $686.91 \pm 164.86$ & $707.78 \pm 525.09$ & $212.19 \pm 87.5$ \\
& & $P=0.6796$ & $P=0.4694$ & $P=0.2563$ & $P=0.3845$ & $P=0.6118$ & $P=0.2819$ \\
\hline HAS3 expression & & & & & & & \\
Negative & 21 & $344.49 \pm 242.18$ & $3.950 \pm 3.684$ & $8.010 \pm 16.122$ & $744.57 \pm 157.21$ & $798.76 \pm 625.46$ & $252.67 \pm 122.38$ \\
Positive & 29 & $385.43 \pm 229.38$ & $2.819 \pm 2.778$ & $6.276 \pm 14.460$ & $674.52 \pm 196.27$ & $691.24 \pm 443.27$ & $202.90 \pm 77.48$ \\
& & $P=0.5061$ & $P=0.2226$ & $P=0.6919$ & $P=0.1832$ & $P=0.4798$ & $P=0.0848$ \\
\hline
\end{tabular}

Values are shown as mean $\pm \mathrm{SD}$.

had a significantly shorter disease-free survival (Figure 2). The multivariate analysis revealed that the SHAP-HA complex was the significant independent variable for the diseasefree survival of endometrial cancer patients (Table 6). The Kaplan-Meier analysis revealed that the patients with elevated serum level of the SHAP-HA complex had a significantly shorter overall survival although no significant difference was found in relation with the serum TIMP-1 levels, depth of myometrial invasion, and histological grade (Figure 3). However, no significant variable was observed in the multivariate analysis for overall survival (Table 7).

\section{Discussion}

The multistage process of tumor invasion and metastasis depends on several mechanisms, including the stimulation of cell growth by growth factors, destruction of the extracellular matrix by proteolytic enzymes [26], neovascularization due to the presence of angiogenic factors $[27,28]$, and cell-tocell or stromal cell interaction regulated by cell adhesion molecules and pericellular matrix molecules.

Significantly increased levels of HA are often associated with certain types of human tumors, and the levels of HA in 

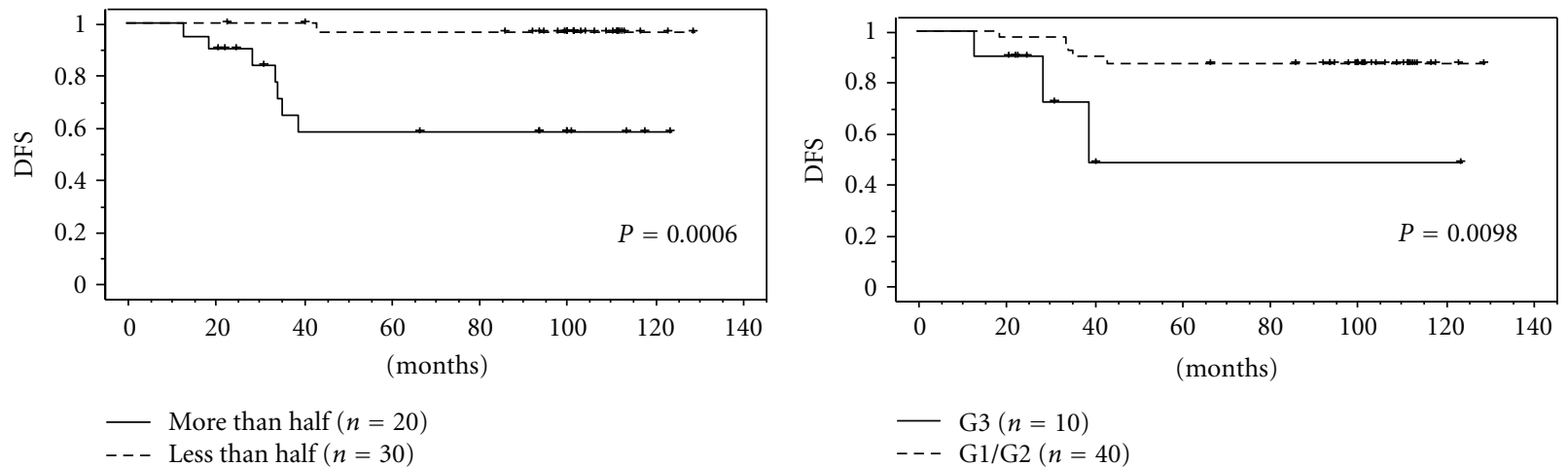

(a)
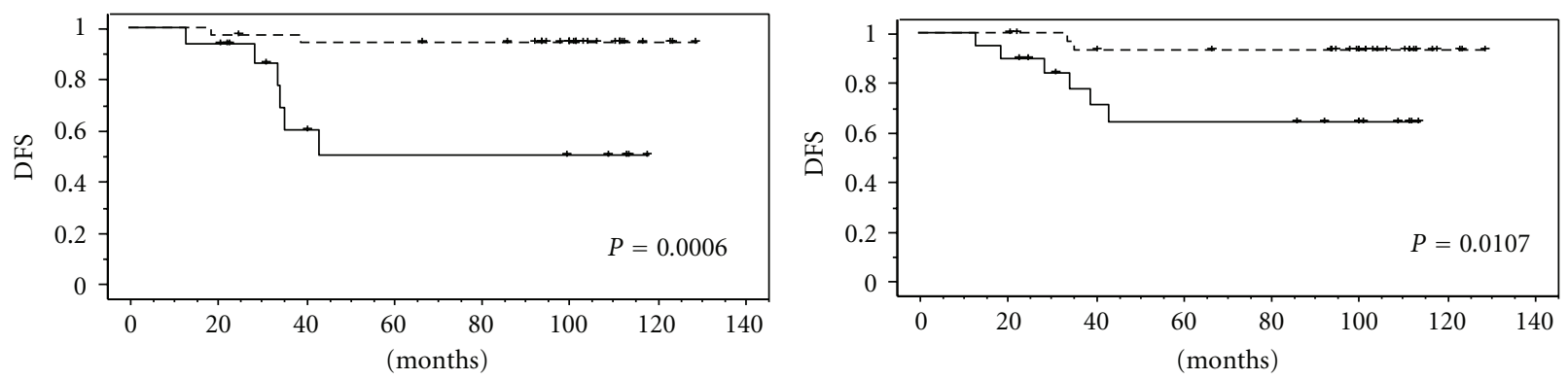

- SHAP-HA complex $>4.7 \mathrm{U} / \mathrm{mL}(n=16)$
- - SHAP-HA complex $\leq 4.7 \mathrm{U} / \mathrm{mL}(n=34)$

TIMP-1 $>212.9 \mathrm{ng} / \mathrm{mL}(n=19)$

- - TIMP- $1 \leq 212.9 \mathrm{ng} / \mathrm{mL}(n=31)$

(c)

(d)

FIGURE 2: Disease-free survival in endometrial cancer patients was analyzed by the Kaplan-Meier method and log-rank test. The patients with the deeper myometrial invasion, poorly differentiated tumor, elevated serum level of the SHAP-HA complex, and elevated serum level of TIMP-1 had a significantly shorter disease-free survival. The maximal normal level in serum of the SHAP-HA complex in serum was determined as $4.7 \mathrm{U} / \mathrm{mL}$ for the SHAP-HA complex and as $212.9 \mathrm{ng} / \mathrm{mL}$ for TIMP-1, which were a value of the mean +2 SD in 50 healthy women.

TABLE 5: Correlationship between the serum HA, SHAP-HA complex, MMP-2, MMP-9, TIMP-1, and UTI in patients with endometrial cancer.

\begin{tabular}{lcc}
\hline Variables & $r$ & $P$ value \\
\hline HA and SHAP-HA complex & 0.466 & 0.0005 \\
HA and UTI & 0.306 & 0.0305 \\
HA and MMP-2 & 0.007 & 0.9635 \\
HA and MMP-9 & 0.345 & 0.0137 \\
HA and TIPM-1 & 0.364 & 0.0089 \\
SHAP-HA complex and UTI & 0.235 & 0.1004 \\
SHAP-HA complex and MMP-2 & 0.066 & 0.6523 \\
SHAP-HA complex and MMP-9 & 0.455 & 0.0008 \\
SHAP-HA complex and TIMP-1 & 0.396 & 0.0041 \\
UTI and MMP-2 & -0.061 & 0.6739 \\
UTI and MMP-9 & 0.071 & 0.6242 \\
UTI and TIMP-1 & 0.255 & 0.0736 \\
MMP-2 and MMP-9 & 0.032 & 0.827 \\
MMP-2 and TIMP-1 & 0.386 & 0.0053 \\
MMP-9 and TIMP-1 & 0.677 & $<0.0001$ \\
\hline
\end{tabular}

the sera of some cancer patients are significantly higher than those of normal individuals $[7,29,30]$. Although increased
HA synthesis is not a universal characteristic of tumors, there seems to be an overall tendency for transformed cells to exhibit higher levels of HA production [31]. In addition, a close relationship has been demonstrated between HA production and malignant phenotypes, such as invasiveness [32]. Our group and another group found that highly metastatic cell lines release more HA into culture medium than less metastatic variants [6]. Furthermore, Zhang et al. [33] reported that $\mathrm{HA}$ on the surface of tumor cells is correlated with metastatic behavior.

HA has either directly or indirectly been implicated in cell adhesion, motility, growth, and differentiation [34]. HAbinding proteins regulate these cellular behaviors by interacting with HA and forming the HA pericellular matrix [35]. Increased matrix deposition of HA may favor tumor growth and invasion by increasing tissue hydration and providing a suitable environment for cell migration analogous to embryonic cell movement. Other mechanisms may also help tumor growth and invasion. For example, the HA pericellular coat may reduce the access and attack of immune cells to tumor cells [36]. Tumor cells are surrounded by a thick pericellular coat that is sensitive to hyaluronidase. The removal of this coat may allow lymphocytes to exert their cytolytic effect on tumor cells. Additionally, partially degraded HA fragments 


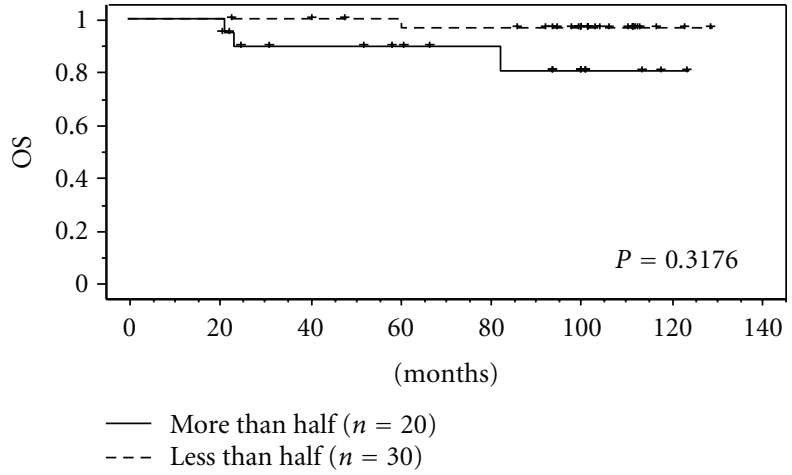

(a)

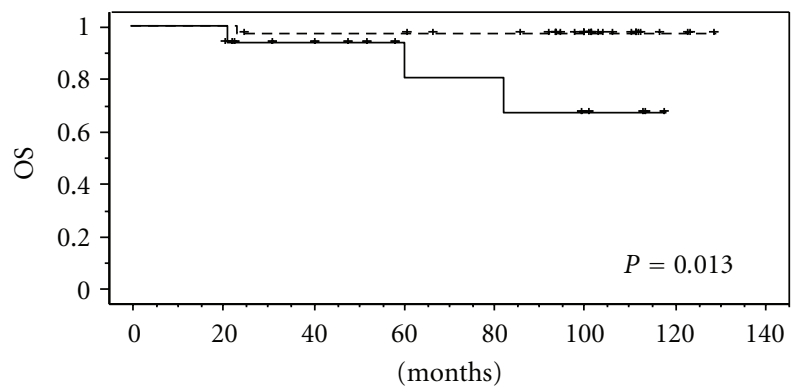

- SHAP-HA complex $>4.7 \mathrm{U} / \mathrm{mL}(n=16)$

- - SHAP-HA complex $\leq 4.7 \mathrm{U} / \mathrm{mL}(n=34)$

(c)

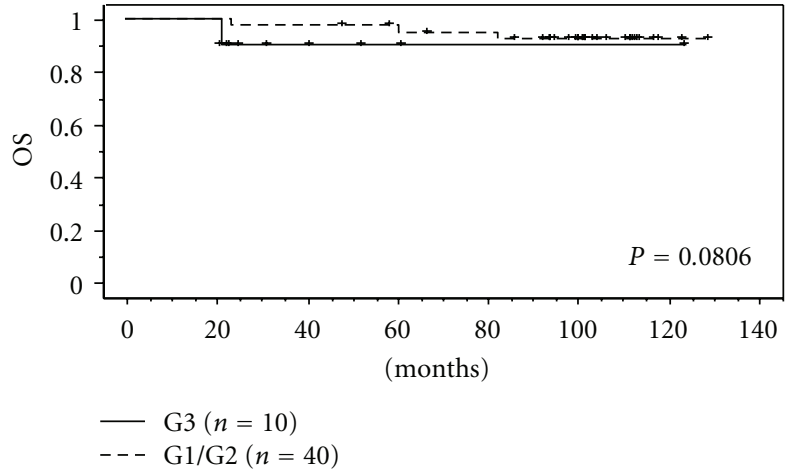

(b)

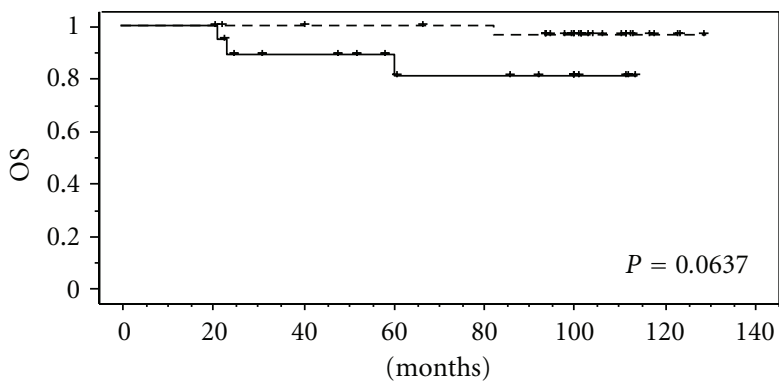

TIMP-1 $>212.9 \mathrm{U} / \mathrm{mL}(n=19)$

- - TIMP- $1 \leq 212.9 \mathrm{U} / \mathrm{mL} 0(n=31)$

(d)

FIgure 3: Overall survival in endometrial cancer patients was analyzed by the Kaplan-Meier method and log-rank test. The patients with elevated serum level of the SHAP-HA complex had a significantly shorter overall survival.

TABLE 6: Hazard ratios for disease-free survival with 95\% CIs adjusted for HAS, HA, SHAP-HA complex, UTI, MMP-2, MMP-9, TIMP-1, and the clinicopathological manifestations in patients with endometrial cancer.

\begin{tabular}{lccc}
\hline Variables & Hazard ratio & $95 \%$ CI & $P$ value \\
\hline $\begin{array}{l}\text { Age } \\
\begin{array}{l}\text { Myometrial invasion } \\
\text { (more than half) }\end{array}\end{array}$ & 1.036 & $0.866-1.238$ & 0.7020 \\
$\begin{array}{l}\text { Histological grade } \\
\text { (G3) }\end{array}$ & 3.407 & $0.146-79.578$ & 0.4458 \\
$\begin{array}{l}\text { Lymph-vascular space } \\
\text { involvement }\end{array}$ & 0.892 & $0.010-77.881$ & 0.9602 \\
HAS1 expression & 0.213 & $0.002-23.731$ & 0.5203 \\
HAS2 expression & 0.273 & $0.010-7.258$ & 0.4380 \\
HAS3 expression & 0.132 & $0.002-7.961$ & 0.3325 \\
HA & 0.990 & $0.973-1.007$ & 0.2440 \\
SHAP-HA complex & 1.773 & $1.010-3.111$ & 0.0461 \\
UTI & 1.084 & $0.981-1.198$ & 0.1146 \\
MMP-2 & 0.993 & $0.976-1.011$ & 0.4693 \\
MMP-9 & 1.000 & $0.998-1.002$ & 0.9204 \\
TIMP-1 & 1.008 & $0.984-1.034$ & 0.5074 \\
\hline
\end{tabular}

promote angiogenesis, an important host contribution to tumor cell viability [37].
Our previous study [38] demonstrates that HA synthesized by HAS1 is associated with tumor neovascularization and predicts tumor aggressiveness and patient survival in ovarian cancer. Yamada et al. [39] reported that elevated transcription levels of the HAS1 gene correlated with poor prognosis of human colon cancer. Anttila et al. [40] reported that elevated levels of stromal HA indicate that the tumor is aggressive and predict poor disease outcome in ovarian cancer patients, especially those with serous tumors. Kayastha et al. [41] reported that CD44 expression is associated with the spread of ovarian cancer and is an independent predictor of survival. HA contributes to tumor growth, invasion, and metastasis through cell proliferation, movement, adhesion, and angiogenesis. It is possible that these functions of HA depend on the overexpression of the HAS genes.

In our previous report [38] and the present study, the serum levels of HA and the SHAP-HA complex were both higher in the endometrial cancer group than in the healthy control group, and the increased synthesis of HA in endometrial cancer tissue appeared to depend on the high expression of HAS1. This finding suggests that increased HA reacts with ITI, resulting in the increased levels of the SHAPHA complex. In addition, the serum levels of HA and the SHAP-HA complex in those cancer group were found to be increased in accordance with the depth of myometrial invasion and lymph-vascular space involvement [38], indicating 
TABLE 7: Hazard ratios for overall survival with 95\%CIs adjusted for HAS, HA, SHAP-HA complex, UTI, MMP-2, MMP-9, TIMP-1, and the clinicopathological manifestations in patients with endometrial cancer.

\begin{tabular}{lccc}
\hline Variables & Hazard ratio & $95 \%$ CI & $P$ value \\
\hline $\begin{array}{l}\text { Age } \\
\text { Myometrial invasion } \\
\text { (more than half) }\end{array}$ & 0.848 & $0.583-1.232$ & 0.3859 \\
$\begin{array}{l}\text { Histological grade } \\
\text { (G3) }\end{array}$ & 0.007 & $<0.001-7458.166$ & 0.4799 \\
$\begin{array}{l}\text { Lymph-vascular space } \\
\text { involvement }\end{array}$ & 0.002 & $<0.001-175.169$ & 0.2913 \\
HAS1 expression & - & - & - \\
HAS2 expression & - & - & - \\
HAS3 expression & - & - & - \\
HA & 1.003 & $0.984-1.023$ & 0.7456 \\
SHAP-HA complex & 3.417 & $0.820-12.075$ & 0.0947 \\
UTI & 0.297 & $0.055-1.610$ & 0.1591 \\
MMP-2 & 1.010 & $0.992-1.029$ & 0.2790 \\
MMP-9 & 1.004 & $0.996-1.013$ & 0.3126 \\
TIMP-1 & - & - & - \\
\hline
\end{tabular}

that the increased levels of HA and the SHAP-HA complex are related to tumor invasion and metastasis.

The present study has also demonstrated that the serum levels of MMP-9 and TIMP-1 were significantly higher in the endometrial cancer group than in the healthy control group, and serum MMP-9 was elevated according to the depth of myometrial invasion and lymph-vascular space involvement. There are some reports suggesting that hyaluronan upregulates MMP-9 and TIMP-1 expressions via CD44 signaling [42, 43]. Peng et al. [44] have shown that, in culture of human breast carcinoma cells, antibody-mediated CD44 cross-linking resulted in the colocalization of CD44 and MMP-9, which may augment the level of MMP-9 in the membrane, possibly implicated in the increased capacity of tumor invasion and metastasis. We have shown that SHAP appears to potentiate the interaction resulting in the increased avidity of HA to CD44 and have suggested that SHAP could function in activating CD44 signaling by increasing the interaction with HA [45]. It is likely therefore that the high serum levels of MMP-9 may be consequential reflection of the increased levels of the SHAP-HA complex in endometrial cancer, which explains the present observation that the elevated levels of SHAP-HA complex had a shorter disease-free survival time compared to those patients with normal levels of SHAP-HA complex.

MMPs are known to be inhibited by naturally occurring TIMPs [46]. Thus, TIMPs are also important factors to regulate cancer cell invasion and metastasis. For one example, Runx3 has been shown to suppress gastric cancer metastasis through the inactivation of MMP-9 by the upregulation of TIMP-1 [47]. However, TIMPs were found to have multiple functions [48]. It not only regulates activity of MMPs as their natural tissue inhibitors as described above, but also stimulates tumor growth and malignant transformation. For example, tissue levels of TIMPs in gastric adenocarcinoma [49] and their serum levels in colorectal cancer [50] are reported to reflect roles in predicting the aggressive behaviors of those cancer cells, together with those of MMP9, suggesting that MMP-9 expression is an independent diagnostic valuable for tumor malignancy. Or, the higher levels of TIMPs could reflect some physiological mechanisms of TIMPs expressions to regulate MMPs expressions and activities. Considering those multi- and variable functions of TIMPs, it is reasonable that the present analysis has revealed that the SHAP-HA complex and TIMP-1 were a significant independent variable predicting a shorter disease-free survival.

\section{Conclusion}

The elevation of serum SHAP-HA complex depended on the HAS1 expression and the SHAP-HA complex is a useful marker to predict disease recurrence in endometrial cancer patients. Because the levels of the SHAP-HA complex showed a significant positive correlation with the levels of MMP9 and TIMP-1, the SHAP-HA complex may promote the lymph-vascular space involvement and the synthesis and activation of MMP-9 and TIMP- 1 in the progression of endometrial cancer.

\section{References}

[1] T. Kayama, T. Sobue, K. Katanoda, H. Tsukuma, H. Mikami, and A. Kitai, "Trends in age specific incidence rate," Cancer Statistics in Japan '10, pp. 36-39, 2010.

[2] C. P. Morrow, B. N. Bundy, R. J. Kurman et al., "Relationship between surgical-pathological risk factors and outcome in clinical stage I and II carcinoma of the endometrium: a Gynecologic Oncology Group study," Gynecologic Oncology, vol. 40, no. 1, pp. 55-65, 1991.

[3] P. J. DiSaia, W. T. Creasman, R. C. Boronow, and J. A. Blessing, "Risk factors and recurrent patterns in Stage I endometrial cancer," American Journal of Obstetrics \& Gynecology, vol. 151, no. 8, pp. 1009-1015, 1985.

[4] B. A. Mast, R. F. Diegelmann, T. M. Krummel, and I. K. Cohen, "Scarless wound healing in the mammalian fetus," Surgery Gynecology \& Obstetrics, vol. 174, no. 5, pp. 441-451, 1992.

[5] L. Zhang, C. B. Underhill, and L. Chen, "Hyaluronan on the surface of tumor cells is correlated with metastatic behavior," Cancer Research, vol. 55, no. 2, pp. 428-433, 1995.

[6] K. Kimata, Y. Honma, M. Okayama, K. Oguri, M. Hozumi, and S. Suzuki, "Increased synthesis of hyaluronic acid by mouse mammary carcinoma cell variants with high metastatic potential," Cancer Research, vol. 43, no. 3, pp. 1347-1354, 1983.

[7] W. Knudson, "Tumor-associated hyaluronan: providing an extracellular matrix that facilitates invasion," The American Journal of Pathology, vol. 148, no. 6, pp. 1721-1726, 1996.

[8] W. H. McBride and J. B. Bard, "Hyaluronidase-sensitive halos around adherent cells. Their role in blocking lymphocytemediated cytolysis," The Journal of Experimental Medicine, vol. 149, no. 2, pp. 507-515, 1979. 
[9] N. Itano, T. Sawai, M. Yoshida et al., "Three isoforms of mammalian hyaluronan synthases have distinct enzymatic properties," Journal of Biological Chemistry, vol. 274, no. 35, pp. 25085-25092, 1999.

[10] N. Itano, T. Sawai, O. Miyaishi, and K. Kimata, "Relationship between hyaluronan production and metastatic potential of mouse mammary carcinoma cells," Cancer Research, vol. 59, no. 10, pp. 2499-2504, 1999.

[11] C. Underhill, "CD44: the hyaluronan receptor," Journal of Cell Science, vol. 103, no. 2, pp. 293-298, 1992.

[12] M. Zhao, M. Yoneda, Y. Ohashi et al., "Evidence for the covalent binding of SHAP, heavy chains of inter- $\alpha$ - trypsin inhibitor, to hyaluronan," Journal of Biological Chemistry, vol. 270, no. 44, pp. 26657-26663, 1995.

[13] L. Huang, M. Yoneda, and K. Kimata, "A serum-derived hyaluronan-associated protein (SHAP) is the heavy chain of the inter $\alpha$-trypsin inhibitor," Journal of Biological Chemistry, vol. 268, no. 35, pp. 26725-26730, 1993.

[14] L. Zhuo and K. Kimata, "Structure and function of inter- $\alpha$ trypsin inhibitor heavy chains," Connective Tissue Research, vol. 49, no. 5, pp. 311-320, 2008.

[15] C. Mizon, M. Balduyck, D. Albani, C. Michalski, T. Burnouf, and J. Mizon, "Development of an enzyme-linked immunosorbent assay for human plasma inter- $\alpha$-trypsin inhibitor (ITI) using specific antibodies against each of the $\mathrm{H}_{1}$ and $\mathrm{H}_{2}$ heavy chains," Journal of Immunological Methods, vol. 190, no. 1, pp. 61-70, 1996.

[16] J. P. Salier, "Inter- $\alpha$-trypsin inhibitor: emergence of a family within the Kunitz-type protease inhibitor superfamily," Trends in Biochemical Sciences, vol. 15, no. 11, pp. 435-439, 1990.

[17] L. Zhuo, M. Yoneda, M. Zhao et al., "Defect in SHAP-hyaluronan complex causes severe female infertility. A study by inactivation of the bikunin gene in mice," Journal of Biological Chemistry, vol. 276, no. 11, pp. 7693-7696, 2001.

[18] N. Isnard, J. M. Legeais, G. Renard, and L. Robert, "Effect of hyaluronan on MMP expression and activation," Cell Biology International, vol. 25, no. 8, pp. 735-739, 2001.

[19] C. Fieber, P. Baumann, R. Vallon et al., "Hyaluronan-oligosaccharide-induced transcription of metalloproteases," Journal of Cell Science, vol. 117, no. 2, pp. 359-367, 2003.

[20] H. Yabushita, T. Kishida, K. Fusano et al., "Role of hyaluronan and hyaluronan synthase in endometrial cancer," Oncology Reports, vol. 13, no. 6, pp. 1101-1105, 2005.

[21] N. Kanomata, T. Yokose, T. Kamijo et al., "Hyaluronan synthase expression in pleural malignant mesotheliomas," Virchows Archiv, vol. 446, no. 3, pp. 246-250, 2005.

[22] W. Yingsung, L. Zhuo, M. Morgelin et al., "Molecular heterogeneity of the SHAP-hyaluronan complex: isolation and characterization of the complex in synovial fluid from patients with rheumatoid arthritis," Journal of Biological Chemistry, vol. 278, no. 35, pp. 32710-32718, 2003.

[23] N. Fujimoto, N. Mouri, K. Iwata, E. Ohuchi, Y. Okada, and T. Hayakawa, "A one-step sandwich enzyme immunoassay for human matrix metalloproteinase 2 (72-kDa gelatinase/type IV collagenase) using monoclonal antibodies," Clinica Chimica Acta, vol. 221, no. 1-2, pp. 91-103, 1993.

[24] N. Fujimoto, N. Hosokawa, K. Iwata, T. Shinya, Y. Okada, and T. Hayakawa, "A one-step sandwich enzyme immunoassay for inactive precursor and complexed forms of human matrix metalloproteinase 9 (92 kDa gelatinase/type IV collagenase, gelatinase B) using monoclonal antibodies," Clinica Chimica Acta, vol. 231, no. 1, pp. 79-88, 1994.

[25] S. Kodama, K. Iwata, H. Iwata, K. Yamashita, and T. Hayakawa, "Rapid one-step sandwich enzyme immunoassay for tissue inhibitor of metalloproteinases. An application for rheumatoid arthritis serum and plasma," Journal of Immunological Methods, vol. 127, no. 1, pp. 103-108, 1990.

[26] H. Yabushita, H. Narumiya, K. Hiratake et al., "The association of transforming growth factor- $\beta 1$ with myometrial invasion of endometrial carcinomas through effects on matrix metalloproteinase," Journal of Obstetrics and Gynaecology Research, vol. 26, no. 3, pp. 163-170, 2000.

[27] H. Yabushita, M. Noguchi, Y. Obayashi et al., "Angiostatin expression in ovarian cancer," Oncology Reports, vol. 10, no. 5, pp. 1225-1230, 2003.

[28] H. Yabushita, M. Shimazu, M. Noguchi et al., "Vascular endothelial growth factor activating matrix metalloproteinase in ascitic fluid during peritoneal dissemination of ovarian cancer," Oncology Reports, vol. 10, no. 1, pp. 89-95, 2003.

[29] P. K. Auvinen, J. J. Parkkinen, R. T. Johansson et al., "Expression of hyaluronan in benign and malignant breast lesions," International Journal of Cancer, vol. 74, no. 5, pp. 477-481, 1997.

[30] K. Ropponen, M. Tammi, J. Parkkinen et al., "Tumor cellassociated hyaluronan as an unfavorable prognostic factor in colorectal cancer," Cancer Research, vol. 58, no. 2, pp. 342-347, 1998.

[31] J. J. Hopwood and A. Dorfman, "Glycosaminoglycan synthesis by cultured human skin fibroblasts after transformation with simian virus 40," Journal of Biological Chemistry, vol. 252, no. 14, pp. 4777-4785, 1977.

[32] B. P. Toole, C. Biswas, and J. Gross, "Hyaluronate and invasiveness of the rabbit V2 carcinoma," Proceedings of the National Academy of Sciences of the United States of America, vol. 76, no. 12, pp. 6299-6303, 1979.

[33] L. Zhang, C. B. Underhill, and L. Chen, "Hyaluronan on the surface of tumor cells is correlated with metastatic behavior," Cancer Research, vol. 55, no. 2, pp. 428-433, 1995.

[34] T. C. Laurent and J. R. Fraser, "Hyaluronan," The FASEB Journal, vol. 6, no. 7, pp. 2397-2404, 1992.

[35] C. B. Knudson and W. Knudson, "Hyaluronan-binding proteins in development, tissue homeostasis, and disease," The FASEB Journal, vol. 7, no. 13, pp. 1233-1241, 1993.

[36] W. H. McBride and J. B. Bard, "Hyaluronidase-sensitive halos around adherent cells. Their role in blocking lymphocytemediated cytolysis," The Journal of Experimental Medicine, vol. 149, no. 2, pp. 507-515, 1979.

[37] D. C. West, I. N. Hampson, F. Arnold, and S. Kumar, "Angiogenesis induced by degradation products of hyaluronic acid," Science, vol. 228, no. 4705, pp. 1324-1336, 1985.

[38] H. Yabushita, M. Noguchi, T. Kishida et al., "Hyaluronan synthase expression in ovarian cancer," Oncology Reports, vol. 12, no. 4, pp. 739-743, 2004.

[39] Y. Yamada, N. Itano, H. Narimatsu et al., "Elevated transcript level of hyaluronan synthasel gene correlates with poor prognosis of human colon cancer," Clinical \& Experimental Metastasis, vol. 21, no. 1, pp. 57-63, 2004.

[40] M. A. Anttila, R. H. Tammi, M. I. Tammi, K. J. Syrjanen, S. V. Saarikoski, and V. M. Kosma, "High levels of stromal hyaluronan predict poor disease outcome in epithelial ovarian cancer," Cancer Research, vol. 60, no. 1, pp. 150-155, 2000.

[41] S. Kayastha, A. N. Freedman, M. S. Piver, J. Mukkamalla, M. Romero-Guittierez, and B. A. Werness, "Expression of the hyaluronan receptor, CD44s, in epithelial ovarian cancer is an independent predictor of survival," Clinical Cancer Research, vol. 5, no. 5, pp. 1073-1076, 1999.

[42] D. Murray, M. Morrin, and S. McDonnell, "Increased invasion and expression of MMP-9 in human colorectal cell lines by 
a CD44-dependent mechanism," Anticancer Research, vol. 24, no. 2, pp. 489-494, 2004.

[43] L. Alaniz, M. García, P. Cabrera et al., "Modulation of matrix metalloproteinase- 9 activity by hyaluronan is dependent on $\mathrm{NF}-\kappa \mathrm{B}$ activity in lymphoma cell lines with dissimilar invasive behavior," Biochemical and Biophysical Research Communications, vol. 324, no. 2, pp. 736-743, 2004.

[44] S. T. Peng, C. H. Su, C. C. Kuo, C. F. Shaw, and H. S. Wang, "CD44 crosslinking-mediated matrix metalloproteinase-9 relocation in breast tumor cells leads to enhanced metastasis," International Journal of Oncology, vol. 31, no. 5, pp. 11191126, 2007.

[45] L. Zhuo, A. Kanamori, R. Kannagi et al., "SHAP potentiates the CD44-mediated leukocyte adhesion to the hyaluronan substratum," Journal of Biological Chemistry, vol. 281, no. 29, pp. 20303-20314, 2006.

[46] T. Hayakawa, "Tissue inhibitors of metalloproteinases and their cell growth-promoting activity," Cell Structure and Function, vol. 19, no. 3, pp. 109-114, 1994.

[47] Y. Chen, X. Wei, C. Guo et al., "Runx3 suppresses gastric cancer metastasis through inactivation of MM9 by up-regulation of TIMP-1," International Journal of Cancer. In press.

[48] T. Murate and T. Hayakawa, "Multiple functions of tissue inhibitors of metalloproteinases (TIMPs): new aspects in hematopoiesis," Platelets, vol. 10, no. 1, pp. 5-16, 1999.

[49] M. Zhang, G. Zhu, H. Y. Gao, S. P. Zhao, and Y. Xue, "Expression of tissue levels of matrix metalloproteinases and tissue inhibitors of metalloproteinases in gastric adenocarcinoma," Journal of Surgical Oncology, vol. 103, no. 3, pp. 243-247, 2011.

[50] B. Mroczko, M. Groblewska, B. Okulczyk, B. Kedra, and M. Szmitkowski, "The diagnostic value of matrix metalloproteinase 9 (MMP-9) and tissue inhibitor of matrix metalloproteinases 1 (TIMP-1) determination in the sera of colorectal adenoma and cancer patients," International Journal of Colorectal Disease, vol. 25, no. 10, pp. 1177-1184, 2010. 


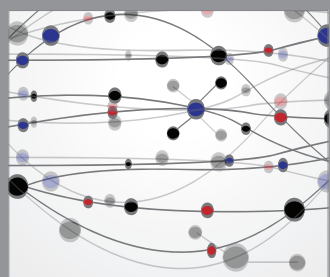

The Scientific World Journal
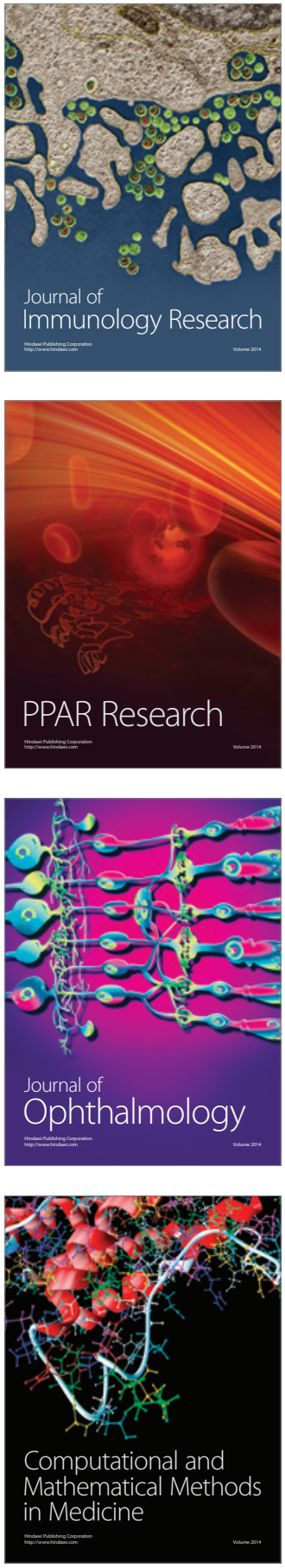

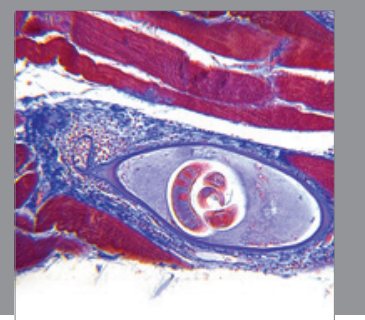

Gastroenterology

Research and Practice
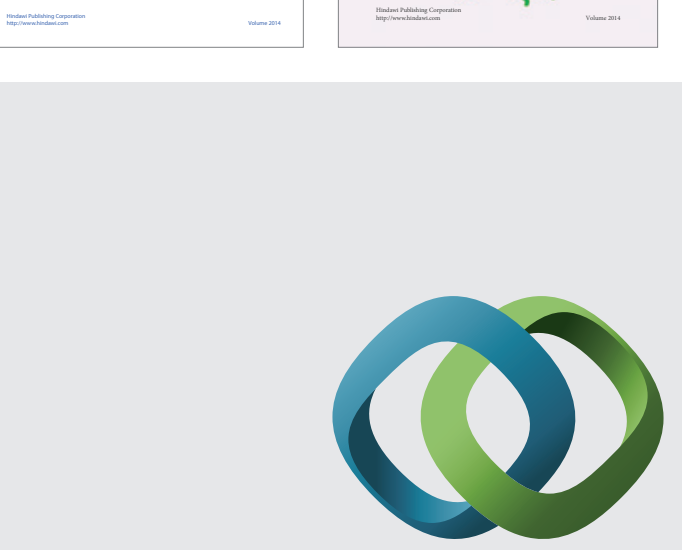

\section{Hindawi}

Submit your manuscripts at

http://www.hindawi.com
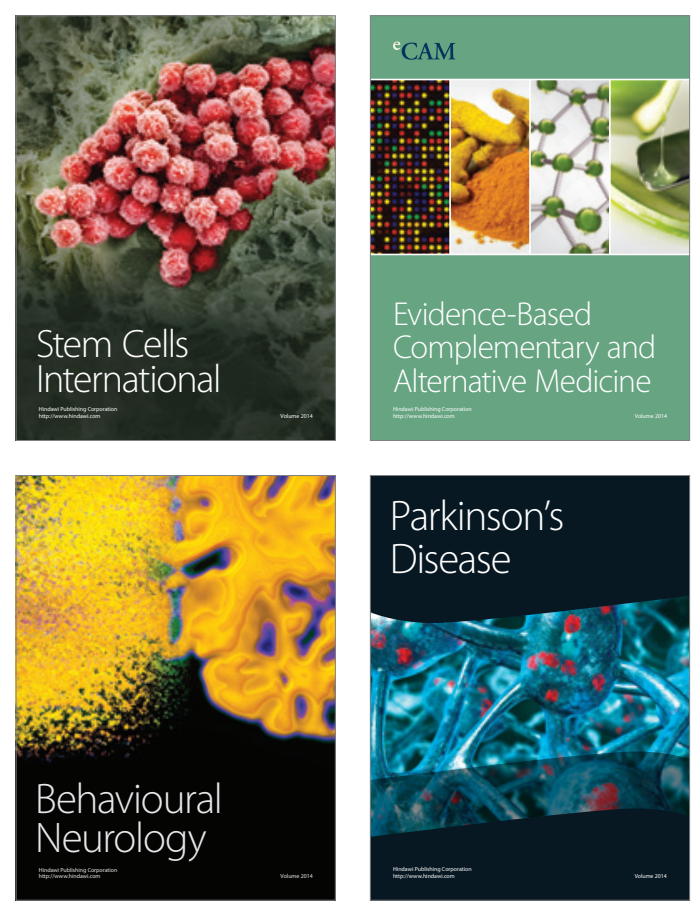

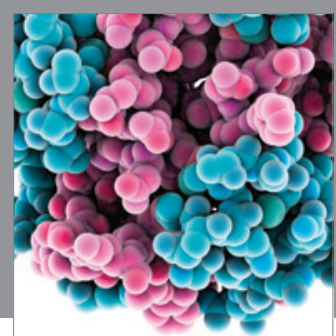

Journal of
Diabetes Research

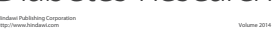

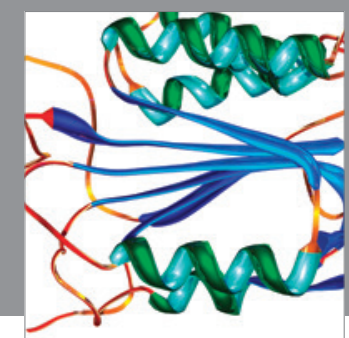

Disease Markers
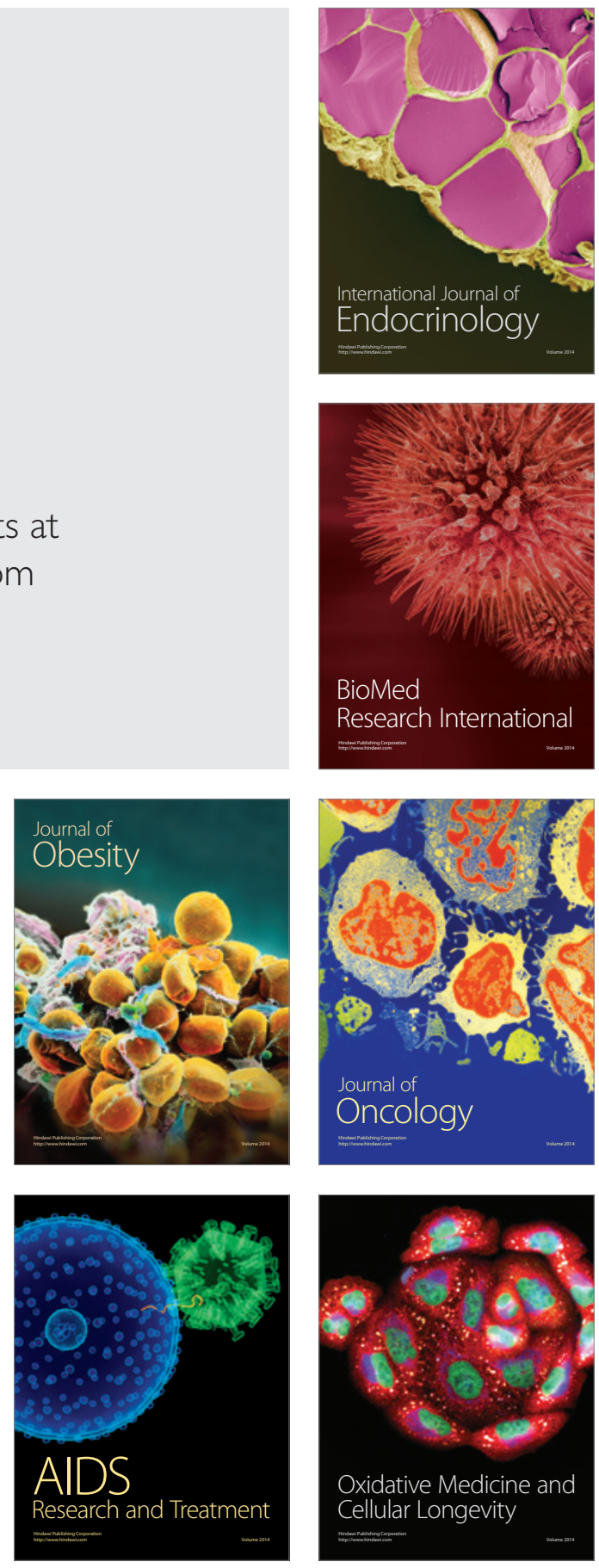